\title{
Dampak media pembelajaran kisah keteladanan terhadap karakter peduli sosial dan prestasi belajar anak sekolah dasar
}

\author{
Selly Rahmawati ${ }^{1}$, Nony Kumala Dewi ${ }^{2}$ \\ ${ }^{1}$ Pendidikan Guru Sekolah Dasar, Universitas PGRI Yogyakarta, D.I. Yogyakarta Indonesia \\ ${ }^{2}$ Pendidikan Guru Sekolah Dasar, Universitas PGRI Yogyakarta, D.I. Yogyakarta Indonesia
}

\section{ABSTRAK}

Membaca dapat mengembangkan pengetahuan, kreativitas, imajinasi dan pola berpikir seseorang. Namun realitanya budaya membaca masyarakat Indonesia sangat rendah. Untuk meningkatkan minat baca, pemerintah dan masyarakat Indonesia telah melaksanakan program-program literasi. Namun program tersebut umumnya hanya dilakukan secara simbolis dan ceremonial. Belum banyak sekolah yang memiliki kebijakan melaksanakan pengintegrasian kegiatan literasi dalam pembelajaran di kelas. Pemanfaatan media pembelajaran kisah keteladanan merupakan satu cara untuk mengintegrasikan kegiatan literasi dalam pembelajaran. Pemanfaatan media kisah keteladanan ini dapat meningkatkan karakter peduli sosial dan prestasi. Pemberian media kisah keteladanan memberikan factor penggerak diluar diri siswa kemudian menginternalisasi dalam factor internal siswa. Kisah Nabi Sulaiman yang dipilih untuk penelitian ini juga memuat nilai teladan peduli sosial. Nilai tersebut merupakan stimulus yang diberikan untuk mempengaruhi sikap siswa. Kisah tersebut dapat mendorong perkembangan psikologis dan emosional yang dapat menanamkan nilainilai pedagogis sehingga dapat mempengaruhi pribadi dan membentuk sikap-sikap moral keteladanan.

\section{ABSTRACT}

Reading can develop a person's knowledge, creativity, imagination, and thinking patterns. However, the reading culture of Indonesian society is deficient. To increase interest in reading, the government and the people of Indonesia have implemented literacy programs. However, these programs are generally only carried out symbolically and ceremonially. Not many schools have policies to integrate literacy activities into learning. The use of exemplary story learning media is a way to integrate literacy activities into learning. The use of exemplary story media can increase the character of social care and achievement. Providing exemplary story media provides a driving factor outside of the student then internalizes it in the student's internal factor. The story of Prophet Sulaiman chosen for this study also contains exemplary values of social care. This value is a stimulus given to influence student attitudes. This story can encourage psychological and emotional development that can instill pedagogical values to influence individuals and shape exemplary moral attitudes.

\section{Sejarah Artikel}

Diterima: 9 Maret 2020

Disetujui: 30 September 2020

Kata kunci:

kisah, peduli sosial, prestasi belajar

\section{Keywords:}

story, social care, learning achievement

\section{Pendahuluan}

Membaca adalah proses kognitif yang terdiri dari menangkap pengetahuan, memahami, menganalisis, sintesis, dan evaluasi. Membaca membuka, mengembangkan dan memajukan pengetahuan, kreativitas, imajinasi dan pola berpikir seseorang. Namun realita yang terjadi di Indonesia adalah budaya membaca masyarakat yang rendah. Hal tersebut dapat dilihat dari World's Most Literate Nations Ranked, tahun 2016 Indonesia berada pada urutan 60 dari 61 negara yang menjadi sampel penelitian. Sementara itu Singapura ada pada urutan 36. Sedangkan Malaysia pada urutan 53 dan Thailand pada urutan 59 (Kompas, 2016). Selain itu berdasarkan survey UNESCO pada tahun 2012 diketahui bahwa indeks tingkat membaca masyarakat Indonesia yang hanya 0,001 persen. Hal tersebut memiliki arti bahwa dari seribu orang hanya satu yang memiliki minat baca. Padahal menurut Darmono \& Putra (2001), "membaca dapat meningkatkan perasaan senang, 
pengetahuan dan dapat digunakan untuk mendukung seseorang dalam melaksanakan pekerjaannya" (hal. 183).

Dalam rangka peningkatan minat baca di Indonesia, pemerintah, dan masyarakat sudah melakukan berbagai upaya seperti program literasi. Program-program literasi tersebut diantaranya adalah Gerakan Indonesia Membaca (GIM), Gerakan Literasi Bangsa (GLB), dan Gerakan Literasi Sekolah (GLS). Namun, pada realitanya program-program tersebut kebanyakan hanya dilakukan secara simbolis untuk pemenuhan indikator akreditasi sekolah yang telah melaksanakan program literasi. Misalnya penempelan poster-poster untuk meningkatkan minat baca menjadi salah satu simbol sekolah telah melaksanakan program literasi pemerintah. Kebijakan-kebijakan peningkatan literasi di sekolah masih sebatas simbolis saja. Belum banyak sekolah yang benar-benar memiliki kebijakan melaksanakan pengintegrasian kegiatan literasi dalam budaya sekolah maupun pembelajaran di kelas.

SD Sonosewu merupakan salah satu SD yang mengintegrasikan kegiatan literasi dengan budaya sekolah. Pada SD tersebut terdapat jam literasi yaitu pada jam ke 0 selama 15 menit. Maksud jam ke 0 adalah jam sebelum dimulainya pembelajaran yaitu jam 07.00-07.15. Pada jam literasi tersebut kegiatan yang dilakukan meliputi membaca nyaring, membaca terpadu, membaca bersama dan membaca mandiri. Namun pada saat observasi pra penelitian, peneliti melihat bahwa jam literasi hanya ada pada jadwal pelajaran saja. Kenyataannya jam literasi umumya digunakan siswa untuk berbincang-bincang dan bermain sebelum memulai pelajaran. Hal tersebut terjadi karena guru kelas tidak menunggui siswa pada jam literasi. Pada saat pembelajaran PPKn guru juga kurang memanfaatkan media buku-buku lain selain buku tematik dan LKS. Sehingga Gerakan literasi di sini hanya menjadi simbol dan wacana saja.

Selain itu pada saat observasi pra penelitian, peneliti juga menemukan beberapa temuan kasus yang berkaitan dengan karakter siswa di SD Sonosewu. Pada saat pembelajaran di kelas rendah siswasiswa sering menyoraki temannya yang salah dalam menjawab pertanyaan guru. Saat Pada saat kelas olahraga di kelas tinggi, juga terjadi perkelahian antar kelas karena ada siswa yang tidak sengaja menyenggol siswa lainnya dari kelas yang berbeda sehingga harus dilerai oleh gurunya. Pada saat pembelajaran di kelas rendah sering terjadi perkelahian-perkelahian kecil antar siswa dan diakhiri dengan salah satu siswa yang menangis. Saat itu teman-teman satu kelas lainnya tetap melaksanakan kegiatan mereka tanpa memperdulikan temannya yang menangis. Begitu pula saat istirahat dan ada yang menjahili atau mengolok-olok temannya, siswa yang lain tidak membela atau melerai, mereka tetap mengobrol di kelas tanpa memperdulikan teman sekelas mereka yang mengalami perundungan. Setelah dilakukan wawancara pra penelitian dengan beberapa guru di SD Sonosewu juga diketahui bahwa siswa-siswi pada kelas rendah memang sering melakukan kekerasan kecil seperti menendang dan memukul karena kurang stabilnya emosi dan kurangnya empati terhadap temannya. Sementara teman sekelasnya pada umumnya juga cuek bila melihat terjadi perkelahian kecil di kelas. Bila ada temannya yang sakit, para siswa kelas tinggi maupun kelas rendah juga tidak ada pemikiran atau rencana menjenguk. Berdasarkan observasi dan wawancara pra penelitian tersebut diketahui bahwa terdapat indikasi bahwa siswa-siswi SD Sonosewu kurang memiliki nilai kepedulian social.

Senada dengan hal diatas, Mikarsa dkk (2007, hal. 23) menyatakan bahwa "orang yang memiliki kepedulian sosial yang tinggi merupakan orang yang memiliki kesadaran sosial yang tinggi. Kesadaran sosial sendiri merupakan kemampuan untuk memahami arti dari situasi sosial". Indikator peduli sosial adalah berempati pada sesama tim kelas, melakukan aksi sosial dan membangun kerukunan warga sekelas (Kemendiknas, 2010). Berdasarkan temuan pra penelitian diatas diketahui bahwa siswa SD Sonosewu kurang peduli terhadap apa yang terjadi pada teman sekelasnya. Walaupun terjadi 
perkelahian kecil, ada yang mengolok maupun menjahili temannya, ada yang menendang dan memukul temannya, umumnya siswa di kelas tersebut tidak peduli dan tetap melakukan aktivitasnya. Hal tersebut merupakan indikasi kurangnya empati pada siswa-siswi di SD Sonosewu. Walaupun ada temannya yang menangis dan sakit, siswa-siswi tersebut tetap tidak melakukan tindakan juga merupakan indikasi kurangnya aksi sosial. Seringnya terjadi perkelahian-perkelahian kecil antar siswa kelas rendah dan kelas tinggi juga menjadi indikasi kurangnya kerukunan di kelas.

Kebiasaan yang diterapkan secara berkala akan membangun karakter seseorang dan bisa dilakukan tanpa diawali dengan rancangan, dengan strategi penanaman karakter melalui kegiatan rutin, kegiatan spontan, dan keteladanan di sekolah (Gunawan, 2012). Salah satu usaha untuk membangun karakter yang baik pada anak untuk mencapai kematangan adalah melalui cerita kisah keteladanan. Subur (2015, hal. 280) menyatakan bahwa "metode bercerita dalam pendidikan dapat membangun sikap moral yang baik dan perasaan takut pada Sang Pencipta". Penyajian kisah pada dunia pendidikan dapat meningkatkan akal pikiran siswa untuk selalu merenung dan melakukan proses pikir sebelum melaksanakan setiap tindakannya (Subur, 2015, hal. 280).

Selain itu beberapa penelitian terkait penggunaan cerita/kisah ini dapat digunakan sebagai pendidikan karakter. Penelitian yang dilakukan oleh Parmini (2015) tentang implementasi dan dampak kisah cerita rakyat bali pada pendidikan karakter siswa SD di Ubud juga menunjukkan hasil berupa satua atau cerita rakyat Bali berdampak positif dalam proses pembentukan karakter siswa kelas tiga Sekolah Dasar di Ubud. Selanjutnya pada penelitian yang dilakukan Soetantyo (2013) tentang peran sebuah kisah dalam pembangunan karakter siswa SD juga menunjukkan bahwa sebuah kisah khususnya kisah dongeng adalah bagian dari budaya rakyat Indonesia yang dapat berpengaruh terhadap moralitas dan karakter anak sehingga kisah dongeng sangat mendukung sebagai cerita pendukung karakter. Dongeng dapat diberikan sebagai langkah untuk menyosialisasikan karakter yang baik yang akan diajarkan di sekolah.

Selain itu metode kisah dan cerita juga merupakan metode pendidikan yang dilakukan Nabi Muhammad SAW. Metode kisah ini menjadi metode yang paling sering digunakan Nabi Muhammad karena dapat merangsang pikiran pembaca/pendengar. Rasulullah menggunakan kisah untuk berbagai tujuan pendidikan misalnya untuk memberitahu masyarakat tentang keutamaan iman, tauhid dan menjauhi syirik, mengasihi dan berhubungan baik dengan sesama manusia, membantu orang yang membutuhkan serta menghiasi diri dengan akhlak mulia (Najati, 2002). Berdasarkan hasil wawancara, guru SD Sonosewu sebenarnya sering menggunakan metode bercerita untuk kelas rendah terutama untuk mata pelajaran Bahasa Indonesia dan PPKn. Namun media dan cerita yang digunakan untuk pembelajaran hanya berbasis pada buku tematik saja sehingga siswa kurang memperhatikan dan prestasi belajar siswa juga kurang baik. Hal tersebut sangat terlihat pada ratarata prestasi belajar PPKn kelas II yaitu 65 yang berada di bawah KKM mata pelajaran PPKn yaitu 75.

\section{Metode}

Penelitian mengambil waktu antara mulai bulan Maret sampai bulan Mei 2019 di SD Sonosewu Ngestiharjo Kasihan Bantul pada kelas II tahun pelajaran 2018/2019. Variabel yang digunakan pada penelitian ini yaitu variabel independent (bebas) yaitu mengenai pengaruh media pembelajaran kisah keteladanan dan variabel dependent (terikat) mengenai peningkatan karakter peduli sosial dan prestasi belajar anak sekolah dasar kelas II.

Teknik pengambilan sampel pada penelitian ini dilakukan melalui teknik non-probabilistic sampling dengan sampling jenuh. Penggunaan teknik ini dengan alasan sampel yang digunakan jumlahnya relatif kecil, kurang dari 30 orang sehingga semua anggota populasi dijadikan sampel. Populasi penelitian ini adalah siswa sekolah dasar kelas II pada SD Sonosewu Ngestiharjo Kasihan 
Bantul dengan sampel dari penelitian ini terdiri atas kelas II A berjumlah 28 anak dan II B berjumlah 26 anak, kelas II A sebagai kelas eksperimen dan kelas II B sebagai kelas kontrol.

Metode pengumpulan data yang umum digunakan dalam suatu penelitian adalah tes, wawancara, kuesioner, observasi, dan dokumentasi. Model tes pada penelitian ini digunakan untuk mengumpulkan data mengenai prestasi siswa dimana tes dalam penelitian ini berbentuk tes pilihan ganda. Wawancara pada penelitian ini digunakan untuk mendapatkan informasi tentang karakter peduli sosial siswa kelas II SD Sonosewu. Lembar kuesioner digunakan untuk melihat perubahan sikap peduli sosial siswa. Lembar observasi digunakan untuk mengobservasi dan memperoleh data partisipasi siswa setelah diberikan media kisah keteladanan terhadap sikap peduli sosial. Metode dokumentasi yaitu mencari data mengenai hal-hal atau variabel yang berupa foto kegiatan siswa.

Instrumen dilakukan uji coba terlebih dahulu di SDN Ngrungkeman dengan tujuan untuk mengetahui apakah instrumen yang disusun benar-benar merupakan instrumen yang baik. Uji instrumen dilakukan dengan alat ukur uji validitas dan uji reliabilitas. Setelah dilakukan uji validitas terdapat 20 butir soal pre-tes dan pos-tes serta 18 butir soal angket peduli sosial yang dinyatakan valid atau dapat digunakan. Teknik analisis yang digunakan pada penelitian ini meliputi uji prasyarat yaitu uji normalitas dan uji homogenitas selanjutnya baru uji independen t-test. Uji normalitas digunakan untuk mengetahui apakah sampel yang diperoleh terdistribusi normal atau tidak. uji homogenitas dilakukan untuk menunjukkan bahwa sampel dari dua kelompok ini memiliki variansi sama. Analisis uji t-test digunakan untuk melihat kecenderungan rata-rata antara kedua kelompok sampel.

\section{Hasil dan Pembahasan}

Penelitian yang dilaksanakan pada 20 - 26 Maret 2019 di kelas II SD Negeri Sonosewu didapatkan hasil nilai pre-tes dan pos-tes, baik dari kelas eksperimen (IIA) dan kelas kontrol (IIB). Kelas eksperimen dilaksanakan di kelas II A dengan jumlah siswa 28 anak, sedangkan kelas kontrol dilaksanakan di kelas IIB dengan jumlah siswa 26 anak. Perlakuan/treatment dilaksanakan pada mata pelajaran PPKn yang terpadu dalam tema hidup rukun sub tema 3 hidup rukun di sekolah pembelajaran ke 2. Kompetensi dasar PPKn dalam sub tema ini adalah bersikap bekerja sama, disiplin dan peduli sesuai sila-sila Pancasila dalam lambang negara garuda pancasila dalam kehidupan seharihari. Indikator dari pembelajaran dua mata pelajaran PPKn ini adalah menjelaskan pengamalan sila kedua Pancasila. Kisah keteladanan yang dipilih dalam penelitian ini adalah kisah Nabi Sulaiman AS. Kisah keteladanan yang digunakan dalam penelitian ini adalah kisah keteladanan Nabi Sulaiman. Kisah Nabi Sulaiman ini dipilih karena Nabi Sulaiman merupakan Nabi yang memiliki kelebihan dalam memimpin manusia, jin dan hewan (Syakir, 2012).

Secara lebih khusus kisah Nabi Sulaiman yang digunakan dalam penelitian ini diambil dari QS. AnNaml ayat 17-19 yaitu saat pasukan Nabi Sulaiman yang terdiri dari jin, manusia dan burung hud menuju wilayah Thaif. Wilayah tersebut sering disebut lembah semut, karena terdapat banyak semut dan sarang-sarang semut di wilayah tersebut. Saat pasukan akan melewati wilayah tersebut ada seekor semut yang memberi pengumuman kepada semut lainnya agar segera masuk ke lubang mereka supaya tidak terinjak pasukan Nabi Sulaiman. Nabi Sulaiman yang dapat memahami bahasa binatang kemudian tersenyum dan menghentikan pasukannya. Pasukan itu baru melanjutkan perjalanan mereka setelah semut-semut tersebut masuk ke dalam sarangnya.

Nabi Sulaiman merupakan putra Nabi Daud yang diberikan mukjizat dapat mengerti dan mendengar binatang-binatang. Selain itu binatang-binatang juga dapat mengerti kata-kata dan perintah Nabi Sulaiman. Dalam kisah keteladanan Nabi Sulaiman terdapat penanaman sikap peduli sosial. Semut merupakan makhluk sosial yang saling membutuhkan dan saling peduli antara satu 
dengan yang lain. Dalam kisah tentang Nabi Sulaiman dan semut, diceritakan bahwa ada seekor semut yang memberitahu kawanan semut bahwa Nabi Sulaiman dan bala tentara akan datang. Ketika hal itu terjadi, kawanan semut yang memiliki badan sangat kecil tentu akan terinjak sehingga seekor semut tersebut memberitahu semut-semut yang lain. Pada kisah tersebut terdapat penanaman nilai karakter peduli, terlihat dari sikap yang ditunjukkan semut pada saat Nabi Sulaiman akan lewat. Sikap tersebut merupakan sikap yang terbentuk karena empati atau kekhawatiran terhadap orang lain. Semut sebagai ciptaan Tuhan yang memiliki karakter sosial dan memiliki sikap peduli antara yang satu dengan yang lainnya (Yaumi, 2014)

Langkah-langkah pembelajaran dalam penelitian ini menggunakan metode story telling yang terbagi dalam tahap persiapan, pembukaan, bercerita, penutup dan evaluasi. Pada tahap persiapan guru menentukan cerita Nabi Sulaiman untuk disampaikan. Setelah itu guru mengondisikan siswa. Guru membagikan buku media pembelajaran kisah keteladanan Nabi sulaiman. Selanjutnya pada tahap pembukaan guru menyampaikan sinopsis cerita kemudian mengenalkan tokoh-tokoh yang akan muncul. Guru kemudian menggambarkan setting lokasi, waktu, ekspresi emosi disertai dengan nyanyian. Pada tahap bercerita, guru bercerita dan memotivasi siswa untuk memberikan respons dan komentar pada bagian tertentu dari cerita tersebut. Guru juga mengawasi pemahaman siswa dengan mengajukan pertanyaan untuk mendalami pemahaman siswa terkait cerita tersebut. Dalam bercerita guru mendorong siswa untuk menduga apa yang akan terjadi pada cerita tersebut. Guru memberikan kesempatan pada siswa untuk melakukan interpretasi cerita. Bila ada kata-kata yang tidak dimengerti maknanya oleh siswa, guru menerjemahkan kata-kata tersebut. Pada tahapan penutup guru melakukan diskusi terkait tokoh-tokoh dan perbuatan yang dilakukan dalam cerita tersebut. Guru melakukan klarifikasi nilai dari perbuatan-perbuatan tokoh tersebut, perbuatan mana yang merupakan perbuatan baik dan perbuatan mana yang merupakan perbuatan buruk. Selanjutnya guru meminta siswa untuk menceritakan kembali cerita tersebut. Pada Langkah memberikan soal evaluasi.

Dampak media pembelajaran kisah keteladanan terhadap peningkatan karakter peduli sosial dan prestasi belajar siswa ini dianalisis menggunakan t-test. Namun sebelum melakukan analisis kuantitatif tersebut, dilakukan uji prasyarat terlebih dahulu. Untuk mengetahui kelas eksperimen dan kelas kontrol terdistribusi normal yaitu menggunakan uji normalitas. Sedangkan untuk mengetahui kemampuan awal siswa pada kedua kelas adalah sama dilakukan uji homogenitas

Pengujian normalitas menggunakan Uji One Sample Kolmogorov Smirnov menggunakan bantuan SPSS 21.

Tabel 1.

Hasil Output Uji Normalitas Pre-tes dan Pos-tes Peduli Sosial

\begin{tabular}{llll}
\hline & Eksperimen & & Kontrol \\
\hline Pre-test & 0,919 & 0,113 & Asymp. Sig (2-tailed) \\
Pos-test & 0,636 & 0,515 & Asymp. Sig (2-tailed) \\
\hline
\end{tabular}

Sumber: Data Hasil Penelitian, 2019.

Tabel 2.

Hasil Output Uji Normalitas Pre-tes dan Pos-tes Prestasi Belajar Siswa

\begin{tabular}{llll}
\hline & Eksperimen & & Kontrol \\
\hline Pre-test & 0,919 & 0,169 & Asymp. Sig (2-tailed) \\
Pos-test & 0,636 & 0,811 & Asymp. Sig (2-tailed) \\
\hline
\end{tabular}

Sumber: Data Hasil Penelitian, 2019.

Seluruh hasil output uji normalitas di atas, baik berdasarkan sikap dan prestasi belajar diketahui bahwa nilai asymp. Sig (2-tailed) untuk nilai kelas eksperimen dan kelas kontrol lebih dari 0,05. Nilai signifikansi >0,05 menunjukkan bahwa kelas eksperimen dan kelas kontrol terdistribusi normal. 
Tabel 3.

Hasil Output Uji Homogenitas Pre-tes dan Pos-tes Peduli Sosial

Levene Statistic

\begin{tabular}{lll}
\hline Pretest & 0,701 & 0,406 \\
Postest & 0,955 & 0,333 \\
\hline
\end{tabular}

Sumber: Data Hasil Penelitian, 2019.

Tabel 4.

Hasil Output Uji Homogenitas Pre-tes dan Pos-tes Peduli Sosial

\begin{tabular}{lll}
\hline Pretest & 0,140 & 0,709 \\
Postest & 0,153 & 0,697 \\
\hline
\end{tabular}

Sumber: Data Hasil Penelitian, 2019.

Hasil uji homogenitas dari kemampuan awal (pre-tes) dan kemampuan akhir (pos-test) pada karakter peduli sosial dan prestasi belajar siswa pada dua kelas yaitu kelas eksperimen dan kelas kontrol adalah sama, yaitu memiliki nilai asymp. Sig (2-tailed) lebih dari 0,05. Nilai tersebut menunjukkan bahwa kelas eksperimen dan kelas kontrol memiliki varian sama sehingga telah memenuhi asumsi dasar homogenitas.

Penelitian yang dilakukan ini berupa pemberian media pembelajaran kisah keteladanan kepada siswa kelas II SD Sonosewu. Siswa kelas IIA (kelas eksperimen) diberikan treatment berupa pemberian media bacaan kisah Nabi Sulaiman AS dalam kegiatan storytelling. Sedangkan siswa kelas IIB (kelas kontrol) melaksanakan kegiatan pembelajaran menggunakan buku tematik biasa. Perlakuan/treatment yang diberikan peneliti pada kelas eksperimen ini merupakan salah satu usaha penanaman karakter yang dilakukan melalui cerita/kisah. Perbedaannya adalah pada kelas eksperimen menggunakan bacaan kisah keteladanan sedangkan kelas kontrol menggunakan cerita yang ada pada buku tematik.

Perlakuan/treatment yang dilakukan oleh peneliti ini merupakan salah satu tahapan pembentukan karakter melalui budaya sekolah yaitu tahap penanaman. Berdasarkan pendapat Sukadari (2018), tahap penanaman ini dilaksanakan dalam beberapa langkah yaitu pengenalan contoh konkret yang baik dan buruk, penjelasan konsekuensi positif dan negatifnya, pemantauan oleh orang tua, guru, dan masyarakat dan langkah pembetulan sikap/karakter yang salah dengan cara yang baik (hal. 138-141). Dalam penggunaan media kisah keteladanan ini, siswa membaca dan mendengarkan cerita tentang kisah Nabi Sulaiman. Dalam cerita tersebut terkandung contoh-contoh baik dan buruk dan contoh akibat dari sikap baik dan buruk. Nilai yang ditanamkan pada kegiatan tersebut juga diawasi oleh guru dalam langkah klarifikasi nilai. Sedangkan pada kelas control siswa hanya membaca cerita umum pada buku tematik.

Setelah itu Damayanti (2014) juga mengemukakan pendapatnya bahwa "implementasi strategi rekayasa nilai meliputi upaya-upaya penciptaan kondisi lingkungan fisik maupun lingkungan sosial yang mendukung aktualisasi nilai-nilai yang telah diiternalisasi dalam diri peserta didik". Upaya-upaya itu berupa keteladanan, pembiasaan nilai-nilai dalam kehidupan nyata sehari-hari, penerapan pemberian penghargaan dan koreksi (reward and punishment), dan sosialisasi dalam organisasi (Damayanti., 2014, hal. 62). Pada penelitian ini siswa kelas eksperimen yang diberikan media kisah keteladanan, hal tersebut berarti ada pembiasaan. Pembiasaan yang dimaksud adalah tahap inisiasi dengan memberikan faktor pendorong dari luar diri siswa yaitu dengan pemberian kisah keteladanan pada siswa. Faktor penggerak eksternal ini kemudian bergerak menjadi faktor internal ketika Sedangkan pada kelas control tidak diciptakan lingkungan telah ada penerimaan terhadap nilai yang 
diberikan tadi dan nilai tersebut kemudian menjadi konsep diri sehingga nilai tersebut menjadi sikap dan perilaku yang menjadi karakter diri.

Perlakuan yang dilakukan oleh peneliti di kelas eksperimen ini dapat mempengaruhi karakter peduli sosial dan prestasi belajar siswa. Hal ini dapat dilihat dari hasil analisis uji independent sample T-test dengan nilai Asymp. Sig (2-tailed) untuk pos-test prestasi dan pos-test angket yang memiliki nilai signifikansi kurang dari 0,05, dimana hal ini menunjukkan adanya perbedaan dari prestasi dan perbedaan sikap peduli sosial pada siswa kelas eksperimen dan siswa kelas kontrol. Berikut ini hasil analisis data uji t-test.

Tabel 5.

Perbandingan Hasil Uji Independen T-test pada Sikap Peduli Sosial Posttest

Nilai Sig (2-tailed)
0,010

Sumber: Data Hasil Penelitian, 2019.

Tabel 6.

Perbandingan Hasil Uji Independen T-test pada Prestasi Belajar PPKn

\begin{tabular}{lc}
\hline & Posttest \\
\hline Nilai Sig (2-tailed) & 0,008 \\
\hline
\end{tabular}

Sumber: Data Hasil Penelitian, 2019.

Pengaruh media kisah keteladanan pada prestasi PPKn dan sikap peduli sosial ini terlihat dari rata-rata pos-test prestasi belajar PPKn dan hasil angket sikap peduli social kelas eksperimen yang lebih tinggi daripada nilai rata-rata prestasi PPKn dan hasil angket kelas kontrol yang terlihat pada gambar berikut.

\section{Gambar 1.}

Rata-rata Prestasi PPKn dan Peduli Sosial

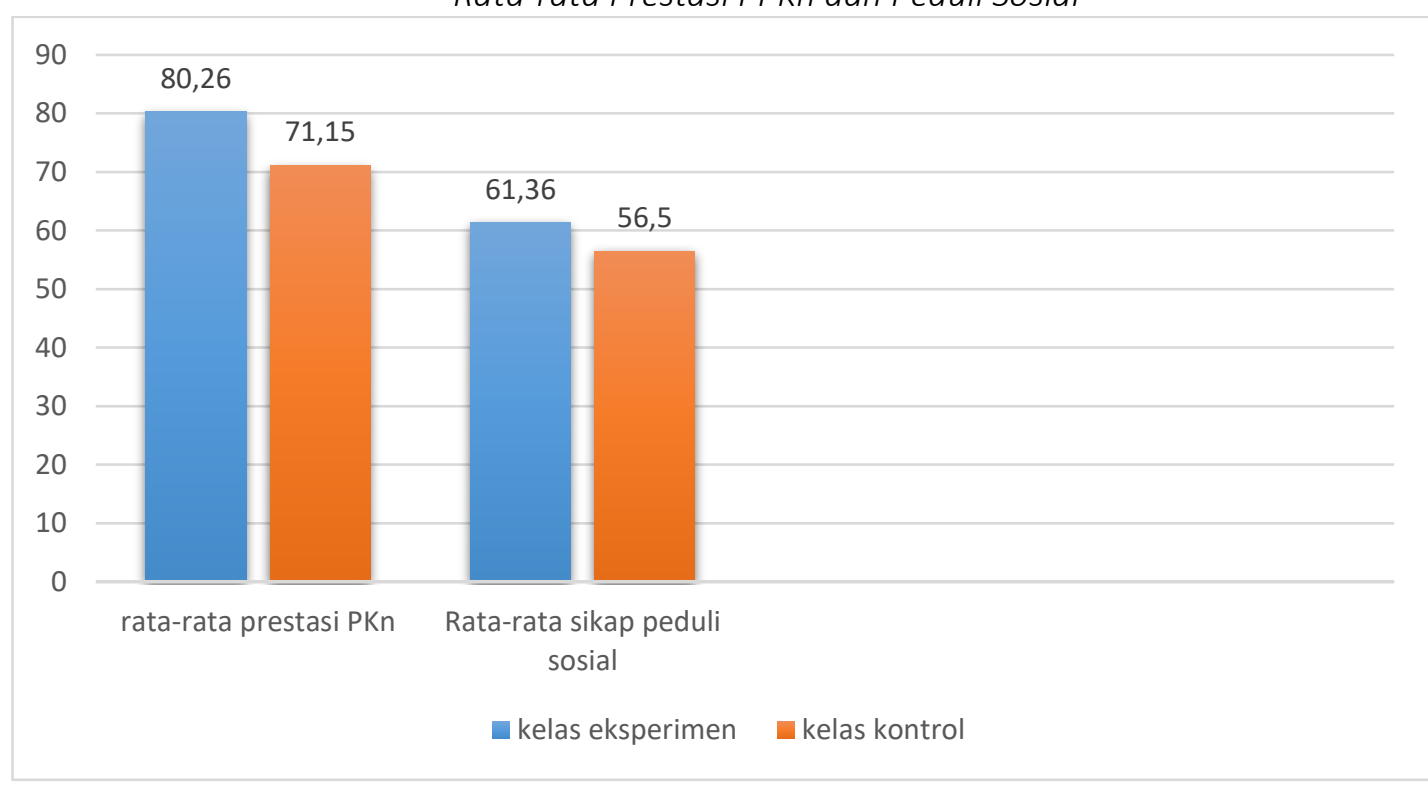

Sumber: Data Hasil Penelitian, 2019.

Temuan ini menunjukkan bahwa penggunaan media pembelajaran kisah keteladanan memberikan pengaruh positif dalam meningkatkan karakter peduli sosial dan prestasi belajar PPKn siswa karena guru menggunakan metode pembelajaran bercerita secara tradisional. Cerita tersebut sangat memotivasi dan lebih mudah bagi siswa untuk menceritakan kembali. Cerita tersebut memungkinkan siswa untuk memodifikasi cerita dengan sentuhan pribadi dan pikiran. Mendongeng 
di kelas dapat membuat siswa dapat menjadi lebih inovatif dan kreatif sambil fokus pada pesan yang ingin mereka komunikasikan (Porter, 2005). Sedangkan Wright et al. (2008), percaya kemampuan mendramatisasi cerita memungkinkan siswa untuk memanfaatkan keterampilan berpikir tingkat tinggi. Siswa mampu membuat dunia nyata koneksi, menunjukkan pemahaman konten, dan lebih mampu mengekspresikan diri dan ide-ide mereka. Teori perkembangan anak telah menekankan bahwa kolaborasi dan berbagi pengalaman membaca dapat mengembangkan keterampilan kognitif (Vygotsky, 1980, hal. 86).

Temuan penelitian ini juga menunjukkan bahwa media pembelajaran kisah keteladanan berpengaruh positif terhadap karakter siswa. Mclean \& Tuite (2016) mengidentifikasi bahwa sebuah cerita berpotensi membuat "cerita buruk" mengalahkan "ilmu yang baik" dalam hal mengomunikasikan pesan atau mengubah perilaku. Haines \& Livesley (2008) menyatakan cerita dapat memfasilitasi refleksi kompas moral, nilai-nilai dan praktik seseorang.

Menurut Piaget \& Gabain (1965) dan Kohlberg \& Goslin Ed. (1969), penggunaan metode mendongeng cocok untuk pengajaran dan pembelajaran Pendidikan Moral, terutama di kalangan anak-anak. Anak-anak belajar nilai-nilai moral melalui cerita dan skenario yang sesuai dengan tingkat kematangan kognitif mereka. Teori Piaget didukung oleh teori Kohlberg \& Goslin Ed. (1969) yang juga menjelaskan bahwa anak-anak belajar nilai-nilai moral melalui pengalaman dan skenario dalam cerita. Studi oleh Pellowski (1990), MacDonald \& Sturm (2001), Vitz (1990), Hui (2005) dan Kilpatrick, (1992) juga mendukung keyakinan bahwa metode bercerita dapat membantu menanamkan nilai-nilai moral pada anak-anak.

Temuan penelitian Madhawa nair et al. (2014) juga menunjukkan bahwa metode bercerita lebih efektif daripada metode konvensional dalam pengajaran Pendidikan Moral di antara siswa kelas lima di sekolah dasar Cina. Metode bercerita membantu meningkatkan minat, motivasi, dan prestasi siswa. Metode ini juga meningkatkan pemahaman siswa tentang nilai-nilai moral. Metode bercerita mampu menarik anak untuk belajar nilai-nilai moral. Penggunaan mendongeng dapat menarik dan merangsang untuk belajar serta membantu meningkatkan motivasi. Metode mendongeng juga lebih berpusat pada siswa dan menciptakan lingkungan belajar yang lebih kondusif dan menyenangkan.

Penelitian Haigh \& Hardy (2011) juga menunjukkan bahwa mendengar cerita dapat membentuk pemahaman, empati, dan refleksi yang lebih besar. Sehingga hubungan, kepercayaan, dan kepedulian dapat dikembangkan melalui bercerita. Beynen \& Bettelheim (1977) berpendapat bahwa cerita dapat digunakan sebagai alat psikologis untuk mendorong perkembangan psikologis dan emosional (hal 178). Senada dengan hal tersebut, Subur (2015) menyatakan pertemuan dan keterlibatan emosi yang menciptakan peluang untuk menanamkan nilai-nilai pedagogis, sehingga tanpa disadari cerita telah berhasil mempengaruhi pribadinya, membentuk sikap-sikap moral keteladanan (hal. 76).

Hal tersebut sesuai dengan penelitian Bahri et al. (2018) tentang tadarus buku yang dilakukan oleh komunitas AARC (Asian African Reading Club). Kegiatan tadarus buku tersebut dapat menguatkan wawasan kebangsaan karena kegiatan membaca buku tersebut memilih buku-buku yang bertema kebangsaan sehingga dapat bisa memperkokoh paham kebangsaan. Selain itu pada sesi pembahasan atau diskusi AARC mengundang penulis, sejarawan, budayawan maupun dosen yang kompeten untuk mengikuti didiskusikan sehingga hal tersebut dapat memperkokoh rasa dan semangat kebangsaan. Kemudian wawasan kebangsaan tersebut membentuk orientasi, persepsi, sikap dan perilaku yang dihayati sehingga menimbulkan rasa kebangsaan, paham kebangsaan dan semangat kebangsaan.

Yvon Ambroise (Azwar, 2000) menjelaskan hubungan antara nilai, sikap, tingkah laku, dan kepribadian sebagai berikut ini. 
Gambar 2.

Bagan Hubungan Antara Nilai, Sikap, Tingkah Laku, dan Kepribadian

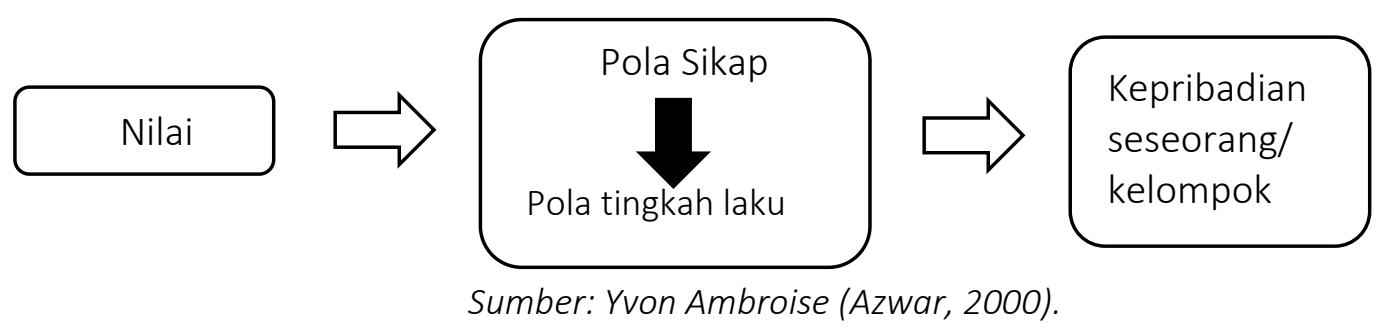

Berdasarkan gambar tersebut, dapat dikatakan bahwa nilai menjadi landasan dalam menentukan sikap dan sikap menjadi landasan dalam bertingkah laku. Tingkah laku akan menentukan kepribadian seseorang. Jadi sikap adalah respons manusia terhadap stimulus yang diberikan. Sikap yang dilakukan secara terus-menerus akan membentuk pola tingkah laku dan pola tingkah laku tersebut akan membentuk karakter.

Menurut Halstead (2007), pendidikan moral berbicara tentang perubahan batiniah, yang merupakan masalah spiritual dan muncul melalui internalisasi nilai-nilai Islam universal. Dua aspek utama pendidikan moral dalam Islam adalah menyebarkan pengetahuan tentang apa yang harus dan tidak boleh dilakukan orang, dan memotivasi mereka untuk bertindak sesuai dengan pengetahuan itu.

Media kisah keteladanan ini mampu menanamkan nilai moral karena menyebarkan pengetahuan tentang apa yang harus dan tidak boleh dilakukan orang pada kisah nabi Sulaiman AS. Muatan yang terdapat dalam kisah Nabi Sulaiman AS ini mengandung banyak sekali nilai-nilai, teladan, dan perilaku yang patut dicontoh oleh peserta didik. Selain itu, kisah Nabi Sulaiman AS merupakan cerita yang non fiksi yaitu cerita yang adanya berdasarkan kenyataan dari perjalanan hidupnya di zaman dahulu sehingga terlihat sangat nyata untuk dilaksanakan dalam kehidupan sehari-hari. Harapannya dengan kisah keteladanan ini mampu dicontoh siswa dalam berperilaku baik pada kehidupannya sehari-hari.

Menurut Dogan (2014), Tuhan telah mengirimkan banyak utusan ke berbagai negara dalam beberapa periode waktu yang berbeda sepanjang sejarah. Utusan atau Nabi adalah teladan terbaik bagi umat manusia dan dia mewakili nilai-nilai kemanusiaan terbaik dalam kodratnya. Nabi menjelaskan arti alam semesta ini dan memperkenalkan Pencipta dengan nama dan atribut-Nya. Pada kisah Nabi-nabi kita dapat menemukan nilai sejati manusia dalam berbagai aspek kehidupannya. Kisah Nabi-nabi dapat menunjukkan keteladanan hidupnya sehingga orang-orang dapat mengikuti jalannya dan menemukan solusi untuk segala macam masalah mereka. Penelitian Ma'arif \& Rofiq (2019) juga menemukan bahwa penanaman nilai di pesantren Daruttaqwa Gresik dengan menceritakan tokoh-tokoh yang menjadi teladan hidup seperti kisah Nabi, sahabat Nabi dan tokoh sufi dapat mengintegrasikan kecerdasan akal dan kecerdasan kalbu untuk menyeimbangkan kepribadian.

Selaras dengan penelitian ini, kelas eksperimen yang diberi media kisah keteladanan dapat menginternalisasikan nilai peduli sosial dan meningkatkan prestasi PPKn. Hal tersebut karena kisah keteladanan Nabi Sulaiman mengandung nilai peduli social. Berdasarkan analisis kisah Nabi Sulaiman yang terkandung dalam QS. An-Naml ayat ke 18 diceritakan bahwa Nabi Sulaiman datang dengan bala tentara di wilayah lembah semut. Nabi mendengar seekor semut memberitahu pada semut-semut lain agar segera masuk ke sarangnya. Karena bila semut-semut tersebut tetap dijalan, semut-semut tersebut akan terinjak oleh nabi Sulaiman dan bala tentaranya. Hal ini menggambarkan bahwa seekor semut tersebut memiliki rasa peduli sosial yang tinggi terhadap semut yang lain. Ketika terdapat bahaya maka salah seekor semut akan memberi peringatan pada semut lainnya agar menyelamatkan 
diri. Sedangkan analisis QS. An-Naml ayat ke 19 yang menggambarkan tentang kekaguman Nabi Sulaiman dengan sikap semut tersebut. Sikap Nabi Sulaiman yang kemudian menghentikan pasukannya juga merupakan contoh sikap peduli terhadap sesama ciptaan Nya. Jadi pada kisah Nabi Sulaiman ini terkandung nilai peduli sosial sehingga siswa kelas II A sebagai kelas eksperimen yang diimplementasikan metode kisah keteladanan memiliki pemahaman lebih tentang sikap peduli sosial dan diiternalisasi ke dalam dirinya dibandingkan kelas kontrol.

\section{Simpulan}

Penelitian ini menekankan sebuah kisah keteladanan dari Nabi Sulaiman yang disampaikan dengan metode storytelling disertai hal-hal baik dan contoh perilaku yang dapat diteladani dari kisah tersebut. Secara kualitatif media kisah keteladanan tersebut dapat meningkatkan karakter peduli sosial dan prestasi yang disebabkan karena pemberian media kisah keteladanan merupakan pembiasaan karakter yang terlihat dari pemberian faktor penggerak diluar dirinya yaitu pemberian media kisah keteladanan yang kemudian menginternalisasi dalam faktor internal siswa. Kisah Nabi sulaiman memang memuat nilai dan sikap teladan peduli sosial yang digambarkan dalam bentuk peringatan yang diberikan semut kepada kawanannya dan sikap Nabi Sulaiman yang menghentikan pasukan. Nilai tersebut merupakan stimulus yang diberikan untuk mempengaruhi sikap siswa. Pengetahuan moral dalam kisah Nabi Sulaiman kemudian memotivasi siswa melakukan sikap peduli social.

Cerita/kisah dapat mengomunikasikan pesan dan mengubah perilaku. Hal tersebut karena cerita/kisah dapat mendorong perkembangan psikologis dan emosional yang dapat menanamkan nilai-nilai pedagogis sehingga dapat mempengaruhi pribadi dan membentuk sikap-sikap moral keteladanan. Metode bercerita dapat membantu meningkatkan minat, motivasi dan prestasi karena membentuk pemahaman, empati dan refleksi. Dengan metode story telling terdapat tahapan penanaman karakter yaitu pemberian contoh baik dan buruk serta pemantauan nilai yang didapat dalam tahap klarifikasi nilai. Langkah menceritakan kisah Kembali pada metode storytelling dapat mendorong siswa lebih inovatif dan kreatif. Menceritakan kisah kembali juga membuat siswa melakukan keterampilan berpikir tingkat tinggi sehingga dapat meningkatkan aspek kognitif siswa.

\section{Ucapan Terima Kasih}

Penelitian ini tidak lepas dari bantuan berbagai pihak untuk itu peneliti mengucapkan terima kasih kepada Universitas PGRI Yogyakarta khususnya LPPM, Kepala Sekolah, Guru, dan Siswa SD Sonosewu yang telah ikut membantu penelitian ini serta redaktur dan reviewer Jurnal Civics UNY yang telah memuat hasil penelitian ini.

\section{Referensi}

Azwar, S. (2000). Sikap manusia: Teori dan pengukurannya. Liberty.

Bahri, H. S., Sapriya, S., \& Halimi, M. (2018). Penguatan wawasan kebangsaan generasi muda melalui kegiatan tadarus buku. Jurnal Civics: Media Kajian Kewarganegaraan, 15(2), 126-133. https://doi.org/10.21831/jc.v15i2.18398

Beynen, G. K., \& Bettelheim, B. (1977). The uses of enchantment. The meaning and importance of fairy tales. The Slavic and East European Journal, 21(3), 396. https://doi.org/10.2307/306589

Damayanti., D. (2014). Panduan implementasi pendidikan karakter di sekolah: Teori dan praktik internalisasi nilai. Araska.

Darmono, \& Putra, R. M. S. (2001). Manajemen dan tata kerja perpustakaan sekolah. Gramedia Widiasarana Indonesia (Grasindo).

Dogan, R. (2014). The exemplary role model Muhammad. FB PUBLISHING.

Gunawan, H. (2012). Pendidikan karakter: Konsep dan implementasi. Alfabeta. 
Haigh, C., \& Hardy, P. (2011). Tell me a story--a conceptual exploration of storytelling in healthcare education. Nurse Education Today, 31(4), 408-411. https://doi.org/10.1016/j.nedt.2010.08.001

Haines, C., \& Livesley, J. (2008). Telling tales: using storytelling to explore and model critical reflective practice in integrated children's services. Learning in Health and Social Care, 7, 227-234. https://doi.org/10.1111/j.1473-6861.2008.00188.x

Halstead, J. (2007). Islamic values: A distinctive framework for moral education? Journal of Moral Education, 36, 283-296. https://doi.org/10.1080/03057240701643056

Hui, M. (2005). Educating" moral" children: Observations from a preschool. University of Hong Kong.

Kemendiknas. (2010). Pengembangan pendidikan budaya dan karakter bangsa. Badan Penelitian dan Pengembangan Pusat Kurikulum.

Kilpatrick, W. (1992). Why Johnny can't tell right from wrong: Moral illiteracy and the case for character education. Simon \& Schuster.

Kohlberg, L., \& Goslin Ed./, D. A. (1969). Stage and sequence; The cognitive-developmental approach to socialization.

Ma'arif, M. A., \& Rofiq, M. H. (2019). The model of character teacher: Phenomenology at Daruttaqwa Gresik Islamic Boarding School. ATTARBIYAH: Journal of Islamic Culture and Education, 3(2), 131. https://doi.org/10.18326/attarbiyah.v3i2.131-152

MacDonald, M. R., \& Sturm, B. W. (2001). The storyteller's sourcebook : a subject, title, and motif index to folklore collections for children, 1983-1999. Gale Group.

Madhawa nair, S., mohd yusof, N., \& Hong, S. (2014). Comparing the effects of the story telling method and the conventional method on the interest, motivation and achievement of Chinese primary school pupils. Procedia - Social and Behavioral Sciences, 116, 3989-3995. https://doi.org/10.1016/j.sbspro.2014.01.878

Mclean, L., \& Tuite, E. (2016). Stories and their value: Exploring the role of storytelling in social care practice. Scottish Journal of Residential Child Care, 15(2), 29-45.

Mikarsa, H. L., Taufik, A., \& Prianto, P. L. (2007). Pendidikan anak di SD. Universitas Terbuka.

Najati, M. U. (2002). Belajar EQ dan SQ dari sunnah nabi. Hikmah.

Parmini, N. P. (2015). Eksistensi cerita rakyat dalam pendidikan karakter siswa SD di Ubud. Jurnal Kajian Bali, 5(2), 1-1.

Pellowski, A. (1990). The world of storytelling. H.W. Wilson.

Piaget, J., \& Gabain, M. (1965). The moral judgment of the child. Free Press.

Porter, B. (2005). Digitales: The art of telling digital stories. Bernajean Porter Consulting.

Soetantyo, S. P. (2013). Peranan dongeng dalam pembentukan karakter siswa sekolah dasar. Jurnal Pendidikan, 14(1), 44-51. https://doi.org/10.33830/jp.v14i1.355.2013

Subur. (2015). Pembelajaran nilai moral berbasis kisah. Kalimedia.

Sukadari. (2018). Implementasi pendidikan karakter melalui budaya sekolah. Kanwa Publisher.

Syakir, A. (2012). Tafsir Ibnu Katsir. In Dar al Sunnah Press.

Vitz, P. (1990). The use of stories in moral development: New psychological reasons for an old education method. The American psychologist, 45, 709-720. https://doi.org/10.1037/0003-066X.45.6.709

Vygotsky, L. S. (1980). Mind in society: The development of higher psychological processes. Harvard university press.

Wright, C., Bacigalupa, C., Black, T., \& Burton, M. (2008). Windows into children's thinking: A guide to storytelling and dramatization. Early Childhood Education Journal, 35(4), 363-369. https://doi.org/10.1007/s10643-007-0189-0

Yaumi, M. (2014). Pendidikan karakter: Landasan, pilar \& implementasi. Prenadamedia. 